probably nearer "the efflux over a weir prolonged on the down stream side, by an open rectangular canal of the same width as the weir," than any other given case of efflux that has been experimented on, so far as they are within the knowledge of the writer. Such experiments are given in Lesbros' Expérience Hydraulique, and on p. 488, Table 42, column headed Fig. 15, are the co-efficients which would probably apply to the case under investigation.* There are reasons for and against the probability of their application to the case in hand. Lesbros' experiments were conducted on a small scale, the length of his weir being only about 8 inches; this would probably make his co-efficients smaller than they should be for our case. Hence, in using them, we remain on the safe side. Then, again, the end of the exterior rectangular canal in his experiments discharged freely into the air, whereas in our case it will discharge into a bay, which again empties into the ocean, about $\frac{1}{4}$ th of a mile from the site of the proposed sluice. As, however, the velocity of the water at low stages of the tide is always very great-some 5 or 6 feet per second-in the lower reaches of the river, and because the level of the water in this bay depends mainly on the state of the tide in the ocean, the two cases may perhaps be considered parallel.

( $T_{0}$ be continued.)

\title{
ON THE DRAUGHT, HEIGHT AND AREA OF SMOKE PIPES, ETC.
}

Bт JoHN Lowe, First Asst. Eng., U. S. N.

WHILE attached to the Asiatic Squadron, this subject was presented to the writer's mind in a practical way. One of our vessels had a poor draught, and these investigations were undertaken to find how much addition to the smoke-pipe would produce a given result. As there is much that is new, perhaps they may not be uninteresting to the readers of the Journal.

If air is forced through an orifice, with a pressure equal to the weight (w $h$ ) of a column of air $(h)$ feet high; it will issue therefrom with the same velocity $(v)$ that a heavy body acquires in falling from the same distance $(h)$ feet.

* They are also given, in part, in the latest American translation of Weisbach's Mechanics, p. 850 , column 4 . 
That is

$$
\mathrm{v}^{2}=2 g h
$$

(Equation 1.)

$g=32 \cdot 2$ the force of gravity.

To consume per second the required amount of fuel, we require (v) cubic feet of air per second, which passes through the area $(a)$ of air interstices in the grate bars with the velocity:

$$
\mathrm{v}=\frac{\mathrm{v}}{a c}, \quad . \quad \cdot \quad \text { (Equation 2,) }
$$

$c$ being a coefficient allowing for the difficulty the air experiences in passing through the bed of coal, etc.

This volume ( $v$ ) of air passing through the fire is heated from the temperature $t$ to $t^{\prime}$, and following Gay Lussac's law expands in volume from $\mathrm{v}$ to $\mathrm{v}^{\prime}$. That is $\mathrm{v}^{\prime}=\mathrm{v}+\mathrm{v}\left(t^{\prime}-t\right) \cdot 00205$.

The specific gravity then of the gas (as we will call the beated air) is $\frac{\mathrm{v}}{\mathrm{v}^{\prime}}=\frac{\mathrm{v}}{\mathrm{v}+\mathrm{v}\left(t^{\prime}-t\right) \cdot 00205}$

$$
=\frac{1}{1+1\left(t^{\prime}-t\right) \cdot 00205}
$$

(Equation 3.)

Hence if the weight of 1 cubic foot of air is $w$, the weight of 1 cubic foot of gas is $1+1\left(t^{\prime}-t\right) \cdot 00 \overline{205}$; the preponderance $\mathrm{P}$ of the air over the gas is per cubic foot $\mathrm{P}=\mathrm{w}-1+\left(t^{\prime}-\frac{\mathrm{W}}{-t) \cdot 00205}\right.$ and the height $\mathbf{H}$ of the stack is the number of the preponderances whose total must become- $\quad \mathrm{P}=\mathrm{w} h$.

Hence $\mathrm{H}=\frac{\mathrm{W} h}{\mathrm{P}}$, or substituting in the last equation

$$
\begin{aligned}
& \mathrm{H}=\frac{\mathrm{Wh}}{\mathrm{W}-\frac{\mathrm{w}}{1+\left(t^{\prime}-t\right) \cdot 00205}} \\
& \overline{\mathrm{H}}=\frac{h}{1-\frac{h}{1+\left(t^{\prime}-t\right) \cdot 00205}} \cdot \quad \text { (Equation 4.) }
\end{aligned}
$$

By experiment $\left(t^{\prime}-t\right)$ that is the difference between the temperature in the stack, and that in the ash pan was found to average $146^{\circ} \mathrm{Fahr}$. Hence equation 4 becomes $\mathrm{H}=\frac{h}{0.2304}$.

We might reduce the entire subject to ore complex formula, but for simplicity will have three, namely:

$$
v^{2}=2 g h . \quad v==\frac{\mathrm{V}}{a c}, \text { by experiment is } 005571 . \quad \mathrm{H}=\frac{h}{0.2304}
$$


For the consurnption of one pound of anthracite 195.45 cubic feet of air is taken to be required.

To conclude. The steps to be taken are: Determine the fuel required to be burnt in toto per second, next determine the area of air interstice in the grate bars.

From these we find first $\mathrm{v}$ and then $v=\frac{\mathrm{v}}{a} \quad \cdot \quad v=\frac{\mathrm{V}}{a \times .005571^{\circ}}$.

Next by substitution find $h=\frac{1}{2 g} \times\left(\frac{\mathrm{v}}{.005571 \times a}\right)^{2}$.

Whence

$$
\mathrm{Ii}=\frac{h}{0.2304} \text {. }
$$

Lastly, the area of the stack is $\mathrm{A}=\frac{a \mathrm{~V}}{112993}$, arising from the same considerations that produce equation 3 .

\section{THE PENNSYLVANIA RAILROAD SHOPS AT WEST PHILADELPHIA.}

- BY Joserh M. Wilson, C. E.

[P. A. Engineer, Construction Department, Pennsylvania Railroad.]

(Continued from page 41.)

Store House.-Plate I gives the location of the store house, it being marked 5. It is intended for the reception of all articles which it is necessary to keep in stock for use in the shops. Plate $\mathrm{X}$ shows the plan of the first floor, a cross section, and a portion of the side elevation of the building.

It will be noticed that the back portion of the house is used for the storage of wrought iron in bars and sheet iron, and has no cellar. The large doors to this apartment are hung on weights, and open by sliding upwards. The front on the first floor is the store room proper, and contains an office for the storekeeper, and a counter, the sides and centre of the room being conveniently fitted up with the necessary shelving, drawers, nail boxes, \&c.

Underneath this portion is a good cellar, having outside and in. side entrances, and is used for storage of heavy articles.

There is a second floor extending over the whole building, communicating by a stairway with the first floor, and having also a hatchway for lifting goods, in the floor directly over the first-story entrance.

Vol, LXII.-Third Series,-No. 2.-August, 1871. 